\title{
Professional Competence of Teachers in Learning Music at Elementary Schools in Pontianak
}

\author{
Imam Ghozali ${ }^{\bowtie}$ \\ Program Study of Performing Arts Education, Department of Language and Art, \\ Faculty of Teacher Training and Education, Universitas Tanjungpura, Indonesia
}

Submitted: May 14, 2020. Revised: June 9, 2020. Accepted: July 4, 2020

\begin{abstract}
Learning the art of music that has characteristics, special characters, and is carried out within an integrative thematic frame in elementary schools, needs to be supported by the professional competence of classroom teachers. The purpose of this study was to determine the professional competence of classroom teachers in learning music in elementary schools. This paper is the result of interpretive descriptive research with the main data source of classroom teachers, while the source of supporting data are students and principals. Data collection techniques are done by tests, observations, and interviews. The data collection process is carried out starting before the learning stage until the learning evaluation process. Based on the results of the study showed that: (1) the average mastery of classroom teachers to the knowledge of music theory needed in learning has only reached $45 \%$; (2) the average teacher mastery of musical basic competencies has only reached $42.5 \%$; and (3) the average teacher mastery of musical instrument playing skills competencies needed in learning has only reached $33.75 \%$. The results of tests conducted on the teachers turned out to be relevant to the data obtained during the implementation of learning. It was proven that learning material in the form of musical knowledge such as music symbols, time bars, and various tempos is only taught by one class teacher. The practice of singing traditional songs is not supported by the teacher's ability to give examples of reading song notation in accordance with the demands of the teacher's handbook. Practical learning material for playing musical instruments is also only implemented by one classroom teacher. The implementation of music art learning in which most of the time allocation is filled with singing songs that are mastered (memorized) by the teacher. This shows that the classroom teacher in the implementation of music art learning has not been supported by adequate professional competence.
\end{abstract}

Keywords: Art and Culture; Learning of Music; Professional Competence

How to Cite: Ghozali, I. (2020). Professional Competence of Teachers in Learning Music at Elementary Schools in Pontianak. Harmonia: Journal of Arts Research And Education, 20(1), 84-94.

\section{INTRODUCTION}

Music education in elementary school (SD) curriculum documents is one part of the four material fields of art material namely, visual, music, dance, and theater, which are thematically accommodated. Seen from the learning material in- tegrated into various themes, the content of music learning in elementary school contains material on bar, rhythm, tone, tempo, dynamics, and sound color. In its implementation it can be developed by the classroom teacher in accordance with the existing grade levels.

The learning process as expected in

\footnotetext{
Corresponding author:

E-mail: imam.ghozali@fkip.untan.ac.id
} 
Government Regulation Number 19 of 2005 which was amended by Government Regulation Number 32 of 2013, and amended again through Government Regulation Number 13 of 2015, stipulates that the education process should be carried out according to certain standards. These standards include content standards, process standards, education standards, facilities and infrastructure standards, management standards, financing standards, and assessment standards. Therefore, the fulfillment of all these standards in the implementation of learning becomes important in order to guarantee the achievement of the expected goals.

The 2015-2019 strategic plan targets two milestones, they are: (1) realizing broad, equitable, and equitable access, and (2) realizing quality learning. In order to achieve these targets, the implementation of learning at the elementary level in Pontianak is still experiencing problems. The two main obstacle are the condition of facilities/infrastructure and human resources. The obstacle related to infrastructure are the availability of classrooms. The number of elementary school classrooms is less comparable to the existing study groups (Rombel). If one study group must use one classroom then there is still a shortage of classrooms at the elementary school level of 657 spaces. This condition is different from the levels of junior and senior high schools, each of which has an excess of classrooms. The shortage of classrooms needed by study groups in elementary schools is compounded by the lack of other facilities such as the UKS Room, Library Room, Computer Room, and other supporting rooms (Central Statistics Agency of Pontianak, 2017).

The obstacle related to human resources is the feasibility of teaching. The level of eligibility of teachers teaching for elementary school levels in Pontianak and surrounding areas is classified as the lowest when compared with the level above it, both junior high and high school. Teachers who are not eligible to teach at the elementary school level are 1,472 people or $52.18 \%$, so there are still more teachers who are not eligible to teach compared to teachers who are worth teaching. Benchmarks for the eligibility of teachers teaching refer to Law Number 14, 2005 concerning Teachers and Lecturers (Law No.14 / 2005). Teachers who are deemed worthy of teaching at the elementary, junior high and high school levels are those who have a Bachelor's degree or Diploma IV or higher. The high number of unworthiness is due to a change in policy regarding teacher qualifications at the Elementary School level, from before it was a Diploma II diploma, to a Bachelor's degree qualification.

Teachers as professionals in the field of education must have an understanding of things that are philosophical, conceptual, to the technical nature. Understanding and mastery of teachers in the technical field is closely related to the implementation and management of interactions in learning. In understanding and mastery in the technical field implies that a teacher must have the basic ability to make the design of learning, as well as having the ability to communicate it to students. These basic abilities are competencies that must be possessed by a teacher. Sardiman (2007) specifies that there are ten competencies that must be possessed by a teacher, they are : (1) mastering the material; (2) managing teaching and learning programs; (3) managing classes; (4) using media / learning resources; (5) mastering the foundations of education; (6) managing teaching and learning interactions; (7) assessing student achievement for teaching purposes; (8) know the functions and programs of guidance and counseling in schools; (9) know and organize school administration; and (10) understanding the principles and interpreting the results of educational research for the benefit of teaching.

The ten competencies mentioned above can be grouped as professional and pedagogical competencies. Professional competence includes mastery of materials and mastery of media / learning resources. Mastery of materials means that teachers master aspects of learning material as 
material to be taught. While mastery of media / learning resources is another aspect of teacher professional competence, which allows teachers to use everything, to be used as media or learning resources. Eight other aspects can be grouped in pedagogical competencies, which include everything related to the learning process and the accompanying science. In this definition, evaluation is not discussed, which it is actually an inseparable part of the learning process.

The Principles of teacher professional competence are demonstrated by his ability in mastering the material, and developing a wide and in-depth coverage of the material. In addition it is also added with its ability to understand and describe the substance of the material contained in the curriculum. Related to this, Kosasih (2008) in his thesis explained that, professional competence can be described as: (1) ability to master materials and technical skills (need education and training); (2) knowledge, skills, and basic values that are reflected in the habits of thinking, feeling, and acting; (3) the abilities and characteristics possessed by an employee in the form of knowledge, expertise, and behavioral attitudes required in carrying out the duties of his position; (4) have knowledge about learning and human behavior; and (5) having knowledge and mastering the field of study they foster.

Teachers need professional competencies. By teachers' professional competencies, learning will lead to the goals of education that should be achieved. Because with these competencies the teacher will be able to sort out, choose, and make the right decisions in the design and implementation of learning. This is as stated by Ibrahim (1988), that the ability of teachers as professionals is the key to success in the management of learning activities. Direct interaction between the teacher and his students makes the teacher a figure who will always be seen as an example in various ways. Therefore, in addition to mastery of methods and approaches in learning, mastery of the material is also something that teachers must have. With these abilities, the teacher will be more confident, thus enabling learning to be more developed.

A teacher who carries out music art learning, in particular is also required to have professional competence in the mastery of music teaching materials / fields. Without this, music learning will only enter the cognitive realm. Even if practical learning takes place without knowing the direction and objectives to be achieved according to curriculum requirements, Government Regulation No. 19 of 2005 provides the professional competency guidelines for integrated art teachers across the curriculum as can be seen in the Table 1.

Learning that is carried out in elementary schools currently uses an integrative thematic approach, which is a learning approach that integrates various competencies from various subjects into a variety of basic themes. Thematic learning has the following characteristics: (1) student centered, (2) provides direct experience, 3) the separation of subjects is not very clear, 4) presents concepts from various subjects 5) is flexible, 6) learning outcomes are in accordance with interests and student needs, 7) use the principles of learning while playing and having fun. (Rusman, 2013).

Learning the art of music is one of the teaching materials in elementary schools that are included in thematic learning. Learning the art of music has a correlation with other subjects, as a transfer of learning and transfer of value from other disciplines. Learning art in general aims to develop the ability to think, behave, and value education for himself as an individual, as well as social and cultural beings. According to a teacher, researcher, and editor from the United States who is active in learning art (music), there are 8 basic principles that must be considered in learning art, especially music. The principles consist of:1) Audiation, 2) Music Aptitud 3) Methodology, 4) Learning Squence Activities, 5) Classroom Activities, 6) Early Childhood, 7) Specific Application to Music Instruction, 
Table 1. Competencies of Elementary School Art Teachers

\begin{tabular}{|c|c|c|c|}
\hline Main Competency & Learning Experience & Material Scope & Assesment \\
\hline $\begin{array}{l}\text { 1. Mastering art learn- } \\
\text { ing material widely and } \\
\text { deeply for integrated } \\
\text { and cross-curriculum art } \\
\text { education. }\end{array}$ & $\begin{array}{l}\text { Knowing the importance of the } \\
\text { function of art as an integrative } \\
\text { factor in the implementation of } \\
\text { integrated art education across } \\
\text { the curriculum. }\end{array}$ & $\begin{array}{l}\text { The function of } \\
\text { art in education }\end{array}$ & $\begin{array}{l}\text { Simulation, } \\
\text { Observation } \\
\text { Portfolio }\end{array}$ \\
\hline $\begin{array}{l}\text { 2. Mastering the scien- } \\
\text { tific substance of art in } \\
\text { relation to other fields of } \\
\text { study. }\end{array}$ & $\begin{array}{l}\text { Implementing the scientific sub- } \\
\text { stance of art in relation to other } \\
\text { fields of study in carrying out } \\
\text { learning }\end{array}$ & $\begin{array}{l}\text { The Nature of } \\
\text { Art as a Form of } \\
\text { Aesthetic Com- } \\
\text { munication } \\
\text { Genre and art } \\
\text { function }\end{array}$ & $\begin{array}{l}\text { Simulation, } \\
\text { Observation } \\
\text { Portfolio }\end{array}$ \\
\hline $\begin{array}{l}\text { 3. insight into integrated } \\
\text { education based on } \\
\text { relevant local arts, skills } \\
\text { and culture. }\end{array}$ & $\begin{array}{l}\text { Implementing integrated edu- } \\
\text { cational insights based on arts, } \\
\text { skills and local culture that are } \\
\text { relevant in implementing learn- } \\
\text { ing. }\end{array}$ & $\begin{array}{l}\text { The Nature of In- } \\
\text { tegrated Educa- } \\
\text { tion; Local Arts, } \\
\text { Skills \& Culture } \\
\text { as an Integrated } \\
\text { Education Base }\end{array}$ & $\begin{array}{l}\text { Simulation, } \\
\text { Observation } \\
\text { Portfolio }\end{array}$ \\
\hline $\begin{array}{l}\text { 4. Able to improve the } \\
\text { ability to express and } \\
\text { appreciate art. }\end{array}$ & $\begin{array}{l}\text { Implementing the ability to ex- } \\
\text { press and creatively appreciate } \\
\text { art in learning. }\end{array}$ & $\begin{array}{l}\text { Creative Person- } \\
\text { ality; The Basics } \\
\text { of Art Expres- } \\
\text { sions; The Basics } \\
\text { of Art Apprecia- } \\
\text { tion }\end{array}$ & $\begin{array}{l}\text { Observation. } \\
\text { Assignment }\end{array}$ \\
\hline
\end{tabular}

dan 8) Types and Stages of Audiation (Gordon, 1985). These principles are still relevant enough to be implemented in music learning in the current curriculum.

Learning art at the elementary school level emphasizes aspects of appreciation, expression, and creation, which in the realm of education can be broken down into cognitive, affective and psychomotor. These three domains work simultaneously and cannot be separated from one another. Physical activity and the taste of beauty are contained in the activities of appreciation, exploration, experimentation, and creation through visual language, sound, motion and roles. Each activity includes fostering and providing facilities to express art ideas, work skills and appreciation in the socio-cultural context of the community.

Related to the function of art, learning music in elementary school has functions directly or indirectly. These functions are related to one another and complement and strengthen each other, according to the characteristics of age at the elementary school level. Directly, music functions as a medium of expression, communication, playing, and talent development for students. Indirectly, It serves as a medium of education and media for the development of basic abilities of students, which include: emotions, imitation, social, copyright, aesthetics, and so on. Thus, indirectly music with its flexibility has a very important role as a medium for delivering subjects in other fields, as well as a medium for personality development. This needs to be emphasized, given the learning of art in elementary schools that have a strategic function. The function of art including music can be described as Figure 1.

Music learning as a medium of expression, is an art field that is quite flexible because it does not have to require time, place, or special equipment. Sound as a music medium can be listened to and produced anytime and anywhere, with other people or only alone, known to others or without others knowing. Children can express themselves through singing, with or without accompaniment of musical instruments, overt or covert, all these activities 
can be done.

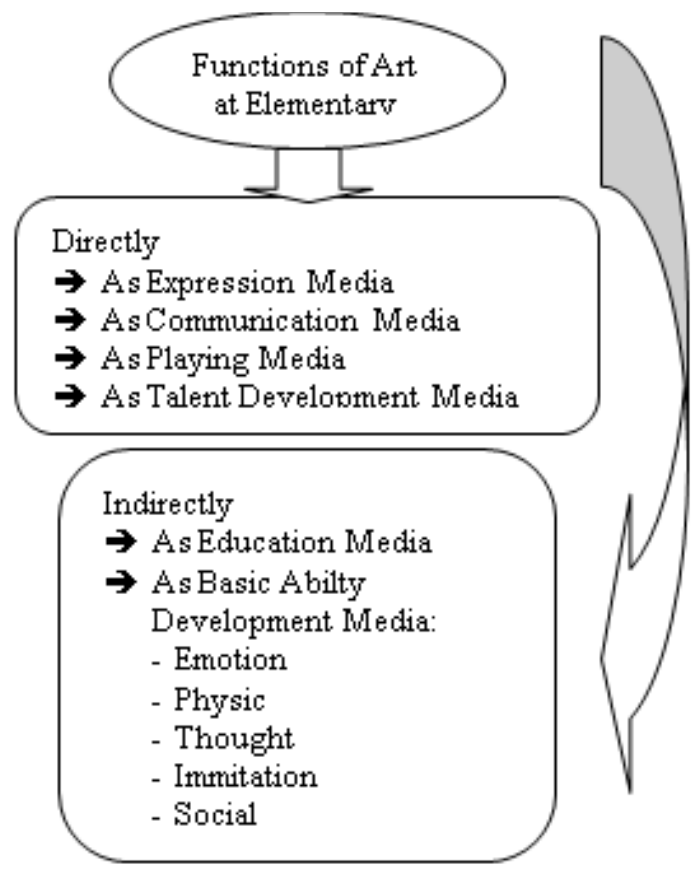

Figure 1. The Functions of Art at Elementary School

Learning music as a medium of communication, because the practice requires more than one subject, namely as a creator and appreciator. For elementary school children, the function of music as a medium of communication is still very limited. Most are still recipients of messages, but within a limited scope elementary school children have also been able to make music as a medium of communication.

Learning music as a medium of play, because music provides a stimulus to move. Basically, playing in children is a movement activity to get pleasure that is not forced. In a variety of games, the song is often the main thing that is used as a companion and media driving the game.

Music learning as talent development, because talent is a potential ability that is not obtained through learning and or training. However, it is necessary to get a media and opportunity to be appreciated by others. Through vocal and instrument music training, musical talents or talents can be developed and get the opportunity to explore and express optimally through sound media. Learning art at the elementary level includes nine important characters (Syukur, 2008). For this reason teachers need to be equipped and equip themselves with competencies related to the area of expertise, namely professional competence. With professional competence, teachers will be able to verify and to choose the music material that are suitable with the character of Elementary School students. Beside that, music learning shoulde arranged in accordance with children's necessity and development. Music can also be able to give supportance to children's creativity.

The characteristic of music used in learning of elementary school student should consider these criteria: (1) melodic and rhythmic patterns that are short and easy to remember, (2) incorporate musical elements such as tempo, dynamics, sound, and musical expression that can be processed and expressed. This is important to provide opportunities for children to gain musical experience, (3) use song poetry that suits the childhood with positive messages, (4) promote local wisdom, and (5) stimulate movement through rhythmic activity of children (Soeteja dkk, 2008: 43).

The learning process through the integrative thematic model in elementary school in the 2013 curriculum for all levels is carried out using a scientific approach. The steps of the scientific approach in the learning process include: digging information through observation, asking questions, experimenting, then processing data or information, presenting data or information, followed by analyzing, reasoning, then concluding, and creating. For learning the art of music, not all of them can be used by the scientific approach. Therefore teachers are required to be able to develop in learning, so it is not fixated on just one approach.

Various studies in music learning show a close relationship between teacher competence and the implementation of learning. The results of the study (Utomo, 2013) show that the competencies needed by a music education teacher in the context 
of implementing action-based learning include: (1) mastery of musical concepts and symbols obtained through various musical experiences (singing, playing musical instruments, creating music, etc.); (2) art music learning strategies that include methods, learning activities, and supporting media; (3) the ability to play an instrument; and 4) the ability to create model songs that are needed in music art learning.

Related to teacher competency, music art learning which is carried out by class teachers in primary schools, is faced with constraints in the form of curriculum coverage, school policies, media, learning resources, and availability of facilities. This has an impact on teachers who feel they do not have sufficient ability to teach art materials, more specifically the art of music. In general, they feel they are not talented, and assume that teachers who teach music education should not be class teachers, but teachers of music subjects.

In another study, Utomo (2010) revealed various obstacles experienced by classroom teachers in learning music arts including (1) the limited ability of teachers to translate the contents of the music arts curriculum, (2) the limited ability of teachers to optimize the potential of children's music art (children become creative and active) (3) the limitations of the teacher in applying the methods used in learning the art of music, (4) the limitations of the teacher in utilizing music learning tools and media (5) the limitations of the teacher in utilizing the potential of the surrounding cultural and natural environment in music learning, and (6) the teacher's limitations in developing forms of music art learning assessment in the classroom.

The low level of knowledge in the assessment and music learning strategies, led to the implementation of learning of elementary school teachers in Puerto Rico running under ideal conditions (López \& León, 2015).

The study also highlighted the lack of music teachers as one of the causes of teaching conditions under the ideal, because the shortcomings are filled by teach- ers from various backgrounds who are not related or do not support their duties as teachers in learning music art.

The purpose of this research is to examine in order to find out (1) how the implementation of music art learning at Elementary School in Pontianak, (2) teacher professional competence in learning music art at Elementary School in Pontianak. The benefit of this research is to develop science in the field of music art learning, and also to determine the professional competence of classroom teachers in learning music art, so that it can be followed up with the preparation of teachers who have professional competence in learning music in elementary school.

\section{METHODS}

This study uses a qualitative workflow with an interpretative analytic method approach. In this research the focus is on aspects related to the professional competence of teachers in the field of music art learning. Thus it can explain the conditions, categorize information, and discover something new. The approach used in this research is the phenomenology approach. The focus in this research relates to professional competence in the implementation of music art learning at Elementary Schools in Pontianak and surroundings.

The main data source in this study is the class teacher in elementary school as the main actor who carries out art learning. This study involved four class teachers from different schools and levels. The determination of the research subject is carried out purposively, with various considerations, which support the implementation of this research.

The instrument in this study was the researcher himself. Researchers as instruments play a role in taking data through interviews with research subjects, observing research subjects and objects, determining documents related to research, and documenting research data. In carrying out its function as an instrument, researchers use test instruments, observation 
guidelines, interview guidelines, and list of documents. To do the test, indicators of knowledge, musicality and instrument playing skills are used.

Data collection techniques used in this study include test, observation, and interview techniques. While the data validity test uses triangulation techniques, namely to check and understand data through various sources, research subjects, methods (theory, methods, techniques), and time. Data analysis in this study uses an interactive analysis model. The data analysis process is carried out simultaneously with data collection. The interactive process is also carried out both when the data collection is still ongoing, for example in the form of comparisons between units, grouping, and final data collection.

\section{RESULTS AND DISCUSSION}

The implementation of learning in four elementary schools as research subjects, refers to the 2013 curriculum. Learning load in K-13 for elementary / MI classes I, II, and III are 30, 32, 34 respectively while for classes IV, V, and VI each 36 hours each week, with elementary / MI study hours are during 35 minutes. With this additional learning hours and a reduction in the number of Basic Competencies, allowing teachers to have more time to develop learning processes that are more oriented to active students. However, this learning needs to be supported with adequate competence, especially teacher professional competence. In accordance with the existing policies, in general the implementation of music art learning which is an integral part of art and culture material, is carried out by the class teacher.

The implementation of music art learning by classroom teachers is carried out in elementary schools where the research is, in accordance with curriculum policies carried out in a thematic frame, with the integration of several subjects. However, the development of learning processes that are oriented towards active students is only limited to physical activities, teachers tend to carry out learning with instructional models. Learning tends to only follow the material contained in the book. THE TRANSFER of material summarized during observation in learning, is still not much different from the previous curriculum, only different in the thematic package.

Music art learning material in elementary schools from grade one to grade six starts from getting to know, differentiate, make, and practice: (1) various rhythmic patterns, (2) tempo and dynamics, (3) short lengths and highs of low notes, (4) simple melodies, (5) simple harmonies (6) musical instruments, and (7) organizing musical performances. Related to curriculum material, especially in learning music, based on the data obtained shows that teachers generally do not submit explanations related to theoretical material. Pada kasus ini siswa lebih sering hanya diminta apa-apa yang tertulis di buku. Meanwhile, to read song notation in the form of number notation, only one subject of research is able to do, the rest choose to hand over to students or choose a song that they know. For material that is musical practice and everything related to musical conditions, almost all of them say they are not capable. Thus, starting at the time of planning, determining the material and indicators of success, implementation, and evaluation of learning can not be arranged in accordance with the substance of the material and learning objectives of music. This is in line with what was stated by Ibrahim (1988) that the key to success in managing teaching and learning activities is the ability of teachers to have professional competence they have. If the teacher does not have professional competence then the decision making in choosing and determining the approach used in the learning process may be incorrect or misdirected.

\section{Professional Competence of Classroom Teachers in Music Arts Learning in El- ementary Schools \\ Referring to several studies on te- acher professional competence (Sardiman,}


2007; Hamzah, 2008; Sugeng et al, (2005); Sukmadinata, 2007; and Permendiknas Number 16, 2007) show that in principle in general teacher professional competence in Music art learning is related to the following matters: 1) Understanding music art teaching material contained in the curriculum and able to develop the scope of music learning material; 2) Understanding the classification of music art material and the principles of its relevance to the interests of music learning in accordance with the objectives to be achieved; 3) Having the ability to use information and communication technology for the benefit of music learning; 4) Have the initiative, willingness, and ability to conduct research in the interests of enhancing the learning of the art of music, and the development of selfprofessionalism; 5) Have the skills to play certain musical instruments and be able to teach the skills they have; 6) Demonstrate the ability to work music, and try to encourage and guide students to actively work.

In learning music in elementary school has different characteristics from the implementation in secondary schools, because it is carried out thematically and integrated with other teaching materials. The professional competence of classroom teachers in learning the art of music in this study is divided into two parts, namely: first, scientific mastery, which includes: (1) conceptual mastery, (2) musical ability, and (3) mastery of instrumental skills, and secondly, mastery in learning which includes: (1) planning, (2) implementation, (3) selection and use of methods, (4) selection and use media, and (5) evaluation. This indicator was taken by adapting the results of research by Utomo (2013) and Syukur (2005).

The results of the ability tests conducted on class teachers as research subjects, showed that in general scientific mastery the research subjects had weaknesses in conceptual mastery and musical mastery. Meanwhile, for mastering the skill of playing musical instruments from four research subjects, one person has the skills to play a musical instrument in either ca- tegory.

From the results of knowledge tests on classroom teachers who carry out music material learning, with material about the concepts of musical elements and the use of musical symbols, it shows that a prominent weakness is the use of musical symbols. This is mainly related to the use of musical symbols used in writing block notation. For the use of numerical notations, in general only know about the mention of tones (solmization), while the duration of each note is not understood. In the following Table 2 is the result of the test of the ability to master knowledge of the class teacher who is carrying out the learning of music material.

Table 2. Test Results of Knowledge Mastery

\begin{tabular}{ccc}
\hline Name & $\begin{array}{c}\text { Concept } \\
\text { Mastery }\end{array}$ & $\begin{array}{c}\text { Music Symbol } \\
\text { Mastery }\end{array}$ \\
\hline Subject 1 & 4 & 2 \\
Subject 2 & 2 & 2 \\
Subject 3 & 3 & 2 \\
Subject 4 & 2 & 2 \\
\hline & $11 / 20$ & $8 / 20$ \\
\hline
\end{tabular}

Value: 1 = Very Poor; 2 = Poor; 3 = Enough; 4 $=$ Good; 5 = Very Good

From Table 2 can be seen that the mastery of knowledge of research subjects is still slightly under $50 \%$ of the overall mastery of knowledge test material. This shows that the level of knowledge of research subjects in general is still inadequate to carry out music art learning. Thus the implementation of theoretical music learning cannot be carried out in accordance with curriculum demands.

For the basic abilities of musical research subjects are done with tone sensitivity tests (listening and imitating tones), interval sensitivity (listening and imitating tone intervals), rhythmic sensitivity (listening and imitating simple rhythmic patterns), and melody sensitivity (listening and imitating simple short melodies). In this test shows lower results when compared to the knowledge ability test, the results of the basic musical ability test as shown in Table 
3.

Based on the Table 3 can be seen that the musical ability of research subjects is lower than the mastery of knowledge $(42.5 \%)$. This has an impact on the implementation of learning. Research subjects tend not to give examples/demonstrate material in the form of songs by singing before the students sing it, especially if they have to sing the notation. That is because in addition to the ability to read music symbols that are still weak, it is also problematic when having to sing certain intervals in the song. If you get material in a book in the form of unknown song notation, another possibility that is often done is to give assignments to students to present / sing at the next meeting, individually or in groups.

In the test of mastery of musical instrument skills showed the lowest results when compared with the mastery of knowledge and musical competence. Only research subjects are able to play more than one instrument, with good and enough categories. While other research subjects are only able to produce one to three notes. For rhythmic instruments, because there are not many choices in each school, only included in other equipment groups. The results of the test are as in Table 4.

Based on the Table 4 can be concluded that the mastery of playing skills of musical instruments of class teachers, overall the lowest when compared with other abilities (33.75\%). Only one class teacher (subject 1) who has the ability skills in the category is quite adequate in playing a musical instrument. So that in the implementation of learning they are concerned more confident and are able to invite students to dig deeper into the material for musical expression.Weaknesses in the mastery of knowledge, musical ability, and mastery of playing musical instruments on average research subjects, affect the implementation of music art learning. The learning implementation includes planning, choosing methods, using media, and also the ability to integrate in a thematic frame, to carrying out the evaluation. The implementation of music art learning carried out by research subjects from observations supported by document studies through analysis of the Learning Implementation Plan (RPP) shows that art teachers in Pontianak elementary schools tend to not meet the criteria as revealed by Sugeng (2005).

The characteristics of elementary school music learning required by Soeteja

Table 3. Results of musical mastery tests

\begin{tabular}{cccccl}
\hline Name & $\begin{array}{c}\text { Tone } \\
\text { Mastery }\end{array}$ & $\begin{array}{c}\text { Interval } \\
\text { Mastery }\end{array}$ & $\begin{array}{c}\text { Rhythm } \\
\text { Mastery }\end{array}$ & $\begin{array}{c}\text { Melody } \\
\text { Mastery }\end{array}$ & \multirow{2}{*}{ Value } \\
\hline Subject 1 & 3 & 3 & 3 & 3 & $5=$ Very Good \\
Subject 2 & 2 & 2 & 2 & 2 & $4=$ Good \\
Subject 3 & 1 & 2 & 3 & 1 & $\begin{array}{l}3 \\
2\end{array}$ Enough \\
Subject 4 & 2 & 2 & 2 & 1 & 1 Poor \\
\cline { 1 - 4 } & $8 / 20$ & $9 / 20$ & $10 / 20$ & $7 / 20$ & \\
\hline
\end{tabular}

Table 4. Test results for mastering musical instrument skills

\begin{tabular}{|c|c|c|c|c|c|}
\hline \multirow[b]{2}{*}{ Name } & \multicolumn{4}{|c|}{ Musical Instrument Mastery / Score Rubric } & \multirow[b]{2}{*}{ Value } \\
\hline & $\begin{array}{c}\text { Piano/ } \\
\text { Keyboard }\end{array}$ & Guitar & Recorder & $\begin{array}{c}\text { Other } \\
\text { Instruments }\end{array}$ & \\
\hline Subject 1 & 3 & 4 & 3 & 2 & \multirow{5}{*}{$\begin{array}{l}5=\text { Very Good } \\
4=\text { Good } \\
3=\text { Enough } \\
2=\text { Poor } \\
1=\text { Very Poor }\end{array}$} \\
\hline Subject 2 & 2 & 2 & 2 & 2 & \\
\hline Subject 3 & 1 & 2 & 1 & 1 & \\
\hline Subject 4 & 1 & 1 & 1 & 1 & \\
\hline & $7 / 20$ & $7 / 20$ & $7 / 20$ & $6 / 20$ & \\
\hline
\end{tabular}


et al (2008) are almost entirely unmet. Of the six criteria implemented only in learning are related to the use of poetry in accordance with the world of children and songs that lead to local wisdom.

Learning materials that have been determined in the curriculum are: (1) rhythmic patterns, (2) tempo and dynamics, (3) short length and high pitch, (4) simple melody, (5) simple harmony (6) musical instrument practice, and (7) music performance, in general only four points are carried out, and even then it is only contained in the practice of singing. While in the form of explanations knowledge is not carried out at all.

The results of this study are in line with the findings of research conducted on the implementation of learning of elementary school teachers in Puerto Rico, which runs under normal and ideal conditions due to the limited knowledge of the teachers in music learning (López \& León, 2015). It is also in line with other studies (Utomo, 2010) that identify the weaknesses of teachers in learning. Likewise, the results of Sun and Leung's (2013) research in China, which found problems with the weaknesses of music learning that result from: 1) inadequate teacher in terms of quantity and quality, 2) inadequate teacher professionalism, 3) the burden of teaching many subjects, and 4) limited knowledge in music learning.

Thus learning music in elementary schools needs to be carried out by art teachers who have professional competencies, in addition to the three other competencies that must be possessed by a teacher, namely pedagogical, personal and social competencies. This needs serious attention in order to achieve the learning objectives of art as mandated and listed in the curriculum document.

\section{CONCLUSION}

The implementation of learning on music art material carried out by classroom teachers Elementary School in Pontianak has not met the criteria for good music learning. Aspects of appreciation, expression, and creation have not yet appeared in learning because learning patterns tend to be instructional. In general, teachers have not demonstrated professional competence, both in scientific mastery and in the implementation of learning. Thus it is necessary to develop partnerships between schools and LPTKs to prepare adequate teachers in the implementation of music art learning.

\section{REFERENCES}

Gordon, E., \& Wood, D. G. (1985). Learning squences activities from jump right in. Chicago: G.I.A. Publications, Inc.

Ibrahim. (1988). Inovasi pendidikan. Jakarta: Departemen Pendidikan dan Kebudayaan Dirjen Dikti, Proyek Pengembangan LPTK.

Kosasih, C. (2008). Kompetensi guru non lulusan pendidikan dalam mengajarkan mata pelajaran seni musik pada tingkat SMP di kota Cianjur. Bandung: Sekolah Pascasarjana UPI.

Leon, R. L. (2015). Music education in puerto rican elementary schools: A study from the perspective of music teachers. International Journal of $\mathrm{Mu}$ sic Education, 33(2), 146-162.

Milles, M. B., \& Huberman, A. M. (1992). Qualitative data analisis. 2007. Analisis data kualitatif, buku sumber tentang metode-metode baru (T. R. Rohidi, ed.). Bandung: UI-Press.

Regelski, T. A. (1981). Teaching general music. Action learning for middle and secondary schools. New York: Schirmner Books, A Division of macmillan Publishing Co., Inc.

Rohidi, T. R. (2011). Metodologi penelitian seni. Semarang: Cipta Prima Nusantara.

Rusman. (2013). Seri manajemen sekolah bermutu: Model-model pembelajaran. Jakarta: PT. Raja Grafindo Persada.

Sardiman, A. M. (2007). Interaksi dan motivasi belajar mengajar. Jakarta: Raja Grafindo Persada.

Soeteja. (2008). Pendidikan seni. Jakarta: Di- 
rektorat Jenderal Pendidikan Tinggi Departemen Pendidikan Nasional.

Soeteja, Z. (2009). Bahan ajar cetak pendidikan seni. Jakarta: Dirjen Dikti Departemen Pendidikan Nasional.

Sukmadinata, N. S. (2007). Pendidikan profesi. In Rujukan filsafat, teori, dan praktis ilmu pendidikan. Bandung: Universitas Pendidikan Indonesia Press.

Sun, Z., \& Leung, B. W. (2014). A survey of rural primary school music education in Northeatern China. International Journal of Music Education, 32(4), 437-461.

Syukur, S. (2005). Peta kompetensi guru seni. Bandung: Dirjen PMPTK Depdikans dan FPBS UPI.
Syukur, S. (2010). Harmoni musik 2. Bandung: Universitas Pendidikan Indonesia.

Utomo, U. (2010). Model pengembangan materi pembelajaran seni musik di SD/MI berdasarkan kurikulum tingkat satuan pendidikan (KTSP). Journal Penelitian Pendidikan (JPP), 27(2), 1-8.

Utomo, U., \& Ardiyarta, T. (2013). Pengembangan instrumen penilaian unjuk kerja (performance assessment) kompetensi ekspresi dan kreasi musik di Sekolah Menengah Pertama (SMP). Harmonia: Journal of Arts Research and Education, 13(1), 1-9. 